$$
\begin{array}{ccccccc}
\text { L } & \text { E } & \text { T } & \text { u } & \text { v } & \text { O } & \text { s } \\
\hline \text { ARCHEOlogija } & 46
\end{array}
$$


Lietuvos istorijos institutas

\begin{tabular}{llllllll}
$\mathrm{L}$ & $\mathrm{I}$ & $\mathrm{E}$ & $\mathrm{T}$ & $\mathrm{U}$ & $\mathrm{V}$ & $\mathrm{O}$ & $\mathrm{S}$ \\
\hline
\end{tabular}

ARCHEOlogija 46 


\section{Leidybą finansavo}

\section{LIETUVOS MOKSLO TARYBA}

PAGAL VALSTYBINĘ LITUANISTINIŲ TYRIMŲ IR SKLAIDOS 2016-2024 METŲ PROGRAMĄ

(Finansavimo sutarties numeris S-LIP-19-4)

\section{Redaktorių kolegija / Editorial board:}

Atsakingoji redaktorė / Editor-in-chief dr. Agnè Čivilytė (Lietuvos istorijos institutas, Vilnius / Lithuanian Institute of History, Vilnius)

Atsakingosios redaktorès pavaduotoja / Assistant Editor dr. Elena Pranckènaitè (Lietuvos istorijos institutas, Vilnius / Lithuanian Institute of History, Vilnius)

Dr. Laurynas Kurila (Lietuvos istorijos institutas, Vilnius / Lithuanian Institute of History, Vilnius)

Dr. Valdis Bērziņš (Latvijos universitetas, Latvijos istorijos institutas, Ryga / University of Latvia, Institute of Latvian History, Riga)

Habil. dr. Anna Bitner-Wróblewska (Valstybinis archeologijos muziejus Varšuvoje, Lenkija / State Archaeological Museum in Warsaw, Poland)

Dr. Christoph Jahn (Baltijos ir Skandinavijos archeologijos centras, Šlèzvigas, Vokietija / Center for Baltic and Scandinavian Archaeology, Schleswig, Germany)

Prof. dr. Rimantas Jankauskas (Vilniaus universitetas, Lietuva / Vilnius University, Lithuania)

Akad. prof. dr. Eugenijus Jovaiša (Lietuvos mokslu akademija, Vilnius / Lithuanian Academy of Sciences, Vilnius)

Habil. dr. Bartosz Kontny (Varšuvos universitetas, Archeologijos fakultetas, Lenkija / Faculty of Archaeology, University of Warsaw, Poland)

Prof. dr. Valter Lang (Tartu universitetas, Estija / University of Tartu, Estonia)

Doc. dr. Algimantas Merkevičius (Vilniaus universitetas, Lietuva / Vilnius University, Lithuania)

Habil. dr. Tomasz Nowakiewicz (Varšuvos universitetas, Archeologijos fakultetas, Lenkija / Faculty of Archaeology, University of Warsaw, Poland)
Habil. dr. Grzegorz Osipowicz (Mikalojaus Koperniko universitetas, Torunè, Lenkija / Nicolaus Copernicus University, Toruń, Poland)

Dr. Gytis Piličiauskas (Lietuvos istorijos institutas, Vilnius / Lithuanian Institute of History, Vilnius)

Dr. Eve Rannamäe (Tartu universtitetas, Estija / University of Tartu, Estonia)

Dr. Andra Simniškyte (Lietuvos istorijos institutas, Vilnius / Lithuanian Institute of History, Vilnius)

Dr. Roberts Spirgis (Latvijos universitetas, Latvijos istorijos institutas, Ryga / University of Latvia, Institute of Latvian History, Riga)

Dr. Eugenijus Svetikas (Lietuvos istorijos institutas, Vilnius / Lithuanian Institute of History, Vilnius)

Dr. Andris Šnē (Latvijos universitetas, Ryga / University of Latvia, Riga)

Doc. dr. Gintautas Zabiela (Klaipédos universitetas, Lietuva / Klaipeda University, Lithuania)

Prof. dr. Šarūnas Milišauskas (Niujorko valstijos Bafalo universitetas, JAV / New York State University at Buffalo, USA)

Prof. dr. Timothy Chevral (Niujorko valstijos Bafalo universitetas, JAV / New York State University at Buffalo, USA)

Prof. dr. Johan Ling (Gioteborgo universitetas, Švedija / University of Gothenburg, Sweden)

Sekretorè / Secretary Dovilè Urbonavičiūtè-Jankauskienė

Redakcijos adresas / Editorial Board address:

Lietuvos istorijos institutas, Archeologijos skyrius

Kražių g. 5, LT-01108 Vilnius

Tel. (+370) 5 2614935, fax (+370) 52611433

e-mail: lietuvosarcheologija@gmail.com;

civilytea@gmail.com

\section{Žurnalas registruotas: EBSCO Publishing: Central and Eastern European Academic Source European Reference Index for the Humanities and Social Sciences (ERIH PLUS)}




\section{TURINYS / CONTENT}

Agnè Čivilytè

Agnè Čivilytè

Jonas Beran

Gabrielè Gudaitienè

Andreas Kotula, Henny Piezonka, Thomas Terberger

Vygandas Juodagalvis

Eglè Šatavičè

Grzegorz Osipowicz, Justyna Orłowska, Gytis Piličiauskas, Giedrẻ Piličiauskienė, Mariusz Bosiak

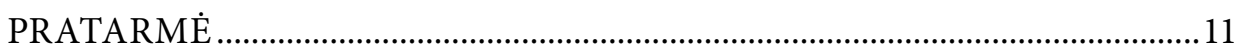

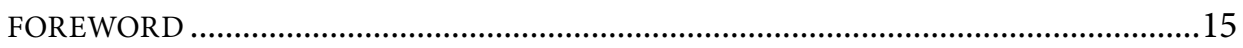

RUDENS POPIETĖ SU RIMUTE RIMANTIENE _.............................................19

AUTUMN AFTERNOON WITH RIMUTE் RIMANTIENĖ

GREETINGS FROM OLD CENTRAL-EASTERN GERMANY:

MEMORIES OF INTERESTING TIMES .27

LINKĖJIMAI IŠ PIETRYČIŲ VOKIETIJOS: PRISIMINIMAI APIE ĮDOMIUS LAIKUS

\section{STRAIPSNIAI / ARTICLES}

EIGULIAI, ONE OF RIMUTE் RIMANTIENĖ'S FIRST EXCAVATIONS A REVISED INTERPRETATION .33

EIGULIAI - VIENA PIRMŲJŲ RIMUTĖS RIMANTIENĖS KASINĖJIMŲ VIETŲ.

NAUJA INTERPRETACIJA

THE MESOLITHIC CEMETERY OF GROß FREDENWALDE (NORTH-EASTERN GERMANY) AND ITS CULTURAL AFFILIATIONS.......65 GROS FREDENVALDE (ŠIAURĖS RYTŲ VOKIETIJA) MEZOLITO LAIKOTARPIO KAPINYNAS IR JO KULTÜRINĖS SĄSAJOS .83

AKMENINIAI GLUDINTI KIRVIAI LIETUVOJE. TIPOLOGIJOS IR TERMINOLOGIJOS PROBLEMOS .85 GROUND STONE AXES IN LITHUANIA. PROBLEMS OF TYPOLOGY AND TERMINOLOGY 108

NEOLITHIC SOCIETIES AND THEIR POTTERY IN SOUTH-EASTERN LITHUANIA 111 NEOLITO BENDRUOMENĖS IR JỤ KERAMIKA PIETRYČIỤ LIETUVOJE. 142

OSSEOUS POINTS AND HARPOON HEADS FROM ŠVENTOJI SUBNEOLITHIC SITES, COASTAL LITHUANIA. FIRST TRACEOLOGICAL INSIGHT INTO THE WAY THEY WERE PRODUCED AND USED 147

KAULINIAI ANTGALIAI IR ŽEBERKLAI LIETUVOS PAJÜRIO ŠVENTOSIOS SUBNEOLITINĖSE GYVENVIETĖSE: GAMYBA IR NAUDOJIMAS PIRMU巳JŲ TRASOLOGINIŲ TYRIMỤ DUOMENIMIS 168 
Sławomir Kadrow

Frédéric Surmely

Rokas Vengalis, Jonas Volungevičius, Gintautas Vèlius, Albinas Kuncevičius, Justina Poškienè, Regina Prapiestienè

Andra Simniškytè

Inga Merkyte்

Rokas Vengalis
MACRO AND MICRO SCALE NEOLITHISATION PROCESSES IN SOUTH-EASTERN POLAND AGAINST THE BACKGROUND OF CENTRAL-EASTERN EUROPE 171

PIETRYČIŲ LENKIJOS NEOLITIZACIJOS PROCESAI MIKRO- IR MAKROLYGMENIMIS VIDURIO IR RYTŲ EUROPOS KONTEKSTE 187

CHARACTERIZATION OF TERTIARY FLINTS BY GEOCHEMISTRY: APPLICATION TO THE FRENCH TERRITORY.

TERCIARO TITNAGO PRANCÜZIJOS TERITORIJOJE CHARAKTERIZAVIMAS NAUDOJANT GEOCHEMINI METODĄ

ŽMOGUS PRIEŠ GAMTĄ: RELJEFO TRANSFORMAVIMAS İRENGIANT XIII-XIV A. KERNAVÉS PILI IR JO SUKELTI EROZINIAI PROCESAI ....... 207 MAN AGAINST NATURE: THE TRANSFORMATION OF THE RELIEF DURING THE CONSTRUCTION OF KERNAVĖ CASTLE IN THE $13^{\mathrm{TH}}-14^{\mathrm{TH}}$ CENTURIES AND THE EROSIONAL PROCESSES IT CREATED 248

KUPIŠKIO (AUKŠTUPĖNŲ) PILIAKALNIS: TEORINĖS PRIELAIDOS

IR TYRIMŲ REZULTATAI .255

HILLFORT OF KUPIŠKIS (AUKŠTUPĖNAI): THEORETICAL ASSUMPTIONS AND INVESTIGATION RESULTS 284

\section{KITAIP APIE ARCHEOLOGIJA /} ALTERNATIVE PERCEPTIONS OF ARCHAEOLOGY

Šarūnas Radvilavičius

KELIAUTOJO LAIKU UŽRAŠAI. 289

THE NOTEBOOK OF TIME TRAVELLER

\section{DISKUSIJOS / DISCUSSIONS}

STUDIES OF ANCIENT DNA. THE RACE FOR THE ULTIMATE ANSWER .293

SENOVĖS DNR TYRIMAI: KARŠTLIGIŠKOS ATSAKYMŲ PAIEŠKOS

\section{RECENZIJOS / REVIEWS}

ALGIMANTAS MERKEVIČIUS (SUD.), 2018. ANKSTYVOJO METALŲ LAIKOTARPIO GYVENVIETÉS LIETUVOJE (SETTLEMENTS OF EARLY METAL PERIOD IN LITHUANIA). 305

INFORMACIJA APIE PROJEKTUS / INFORMATION ABOUT THE PROJECTS 309

AUTORIŲ DĖMESIUI. 327 GUIDELINES FOR AUTHORS 


\title{
MACRO AND MICRO SCALE NEOLITHISATION PROCESSES IN SOUTH-EASTERN POLAND AGAINST THE BACKGROUND OF CENTRAL-EASTERN EUROPE
}

\author{
SŁAWOMIR KADROW \\ Institute of Archaeology, Rzeszów University, Moniuszki 10, 35-015, Rzeszów, Poland, email: slawekkadrow@gmail.com
}

The aim of the article is to outline the causes, mechanisms, and course of the Neolithisation process in South-Eastern Poland, as seen from a global (macro-) and local (microregional) perspective. It has been assumed that the most effective tool for analyzing this process on a macro scale is a set of concepts and rules constituting the theory of globalization (Hodos 2017). Cultural analysis (Wuthnow 1987), on the other hand, considers conflict as the main driving force of deep changes on a micro scale. Globalization is a form of connectivity that is the price humans pay to access resources that satisfy their desire for status and wellbeing. A common human pursuit is the desire to achieve a higher status and to improve one's own wellbeing. People, realizing their intentions and aspirations, enter into conflicts which can potentially be one of the main sources of crises, and thus also of cultural change.

Keywords: Neolithisation, SE Poland, Linear Band Pottery culture, globalization, cultural analysis, conflict.

Šio straipsnio tikslas yra globaliu (makro-) ir vietiniu (mikroregioniniu) lygmenimis apibrěžti pietryčiu Lenkijos neolitizacijos proceso priežastis, mechanizmus ir eigą. Viena vertus, makrolygmens procesai efektyviausiai gali büti atliekami vartojant globalizacijos teorijos sąvokas ir nuostatas (Hodos 2017). Kita vertus, remiantis kultūrine analize (Wuthnow 1987) manoma, kad pagrindinè varomoji didžiuju pokyčiu mikromastu jëga yra konfliktas. Globalizacija yra bendruomeniškumo ir tarpusavio ryšiu palaikymo forma. Tai yra kaina, kurią žmonès sumoka, norédami gauti prieiga prie ištekliu, reikalingu patenkinti ju statuso ir gerovés troškimui. Taigi žmones, suvokdami vienas kito ketinimus ir siekius, ìsitraukia ’̨ konfliktus, kurie gali tapti viena iš pagrindinių krizès ir kultūriniu pokyčiu priežastimi.

Reikšminiai žodžiai: neolitizacija, pietryčių Lenkija, Juostinès linijinès keramikos kultūra, globalizacija, kultūrinè analizè, konfliktas.

\section{INTRODUCTION}

The beginnings of the Neolithic and the Neolithisation processes have always attracted the attention of archaeologists. This has certainly been the case with the Middle East and South-Eastern Europe (e.g. Milojčić 1960), Central Europe (e.g. Nowak 2009), and the Baltic area (e.g. Rimantienè 1979).

The aim of the article is to outline the causes, mechanisms, and course of the Neolithisation process in South-Eastern Poland, as seen from a global (macro-) and local (microregional) perspective.
The spatial scope of the article is bounded by the upper Vistula River basin. The time range begins with the emergence of the oldest farming communities north of the Carpathians, and continues until the Linear Band Pottery culture (hereafter: LBK) groups transformed into the Malice culture (hereafter: MC), which is one of the post-LBK units. It has been assumed that the most effective tool for analyzing the process of Neolithisation on a macro scale is a set of concepts and rules constituting the theory of globalization (Hodos 2017). On the other hand, the cultural analysis of Robert Wuthnow (1987) will 
also serve as an aid to reflect on conflict as the main driving force of deep changes on a micro scale. It is worth emphasizing that both of the aforementioned analytical tools have not been used in Neolithisation studies to date.

The abovementioned analytical tools have been designed to play the role of selected - from among the many possible - specific points of view of the problem of Neolithisation recognised in light of the wider theory of structure (Giddens 1984), the essence of which is the interdependence of structure and agency, or the theory of 'social becoming' (Sztompka 1991), in which there is a continuous synthesis of functioning structures and active subjects (Kadrow 2020b). The first of these social theories has already become the basis of several studies devoted to selected cases of Neolithisation in Europe (cf. Zvelebil 2005; Troskosky et al. 2019).

Social processes take place in an environment consisting of nature and consciousness. Nature is an unavoidable 'container' into which social life flows. People are thinking beings, using symbols, communicating with others, forming beliefs, etc. They are always immersed in an environment of ideas, their own and those of other people, both their contemporaries and predecessors (Sztompka 2007).

Processes on the macro (e.g. globalization) and micro scale (local crises and conflicts) are inextricably linked because they are a consequence of human actions. Human intentions, actions, and their motives are always and only carried out by individuals. They gain their collective social and cultural dimension thanks to habitus (Bourdieu 1972) or routinisation (Giddens 1984).

It is assumed that people work in a routine manner, i.e. in a system (habitus) of embodied dispositions, usually shared by people from a similar cultural milieu, which organises the ways in which individuals perceive the social world around them.

Habitus is the internalisation of external structures (norms, moral orders) and generates strategies that allow a person to deal with different situations in a consistent and systematic way (Kadrow, Müller 2019, p. 11).

It is sometimes difficult to determine the cause and results of the process of change stemming from various trends of the globalization process and local conflicts initiated by the pursuit of aspirations for higher social status and a better life. It often takes the form of a feedback effect.

\section{GLOBALIZATION}

Globalization is a complex connectivity (Robertson 2017, p. 54), 'created by a dense network of interactions and interdependencies between disparate people brought together through the long-distance flow of goods, ideas, and individuals' (Tomlinson 1991). Connectivity is the price humans pay to access resources that satisfy their desire for status and wellbeing. A common human pursuit is the desire to achieve a higher status and to improve one's own being (Robertson 2017, p. 54). People, realizing their intentions and aspirations, enter into conflicts which can potentially be one of the main sources of crises, and thus also cultural change (c.f. Kadrow 2020a).

According to one of many definitions, globalization is a process that encompasses the causes, course, and consequences of the transcultural integration of human behaviour and activities (Feinman 2017, p. 43). This process has no clearly defined beginning or end and may encompass smaller spatial domains than the entire planet. There is no consensus among researchers about the timeframe of globalization processes (Feinman 2017, p. 44). For most researchers, a reasonable timedepth is no more than decades. Others believe that globalization processes began around ad 14501500. Still others shift this beginning back several millennia to the advent of urbanisation and the formation of early states. However, it is known 
that transcontinental migrations and shifts have been typical for the human race at every stage of its development (Feinman 2017, pp. 45-46; Hodos 2017, p. 3). Some researchers emphasize that globalization is a repetitive phenomenon (Jennings 2017, p. 12).

Globalization is a multi-scalar phenomenon in the newest sense of the term, one which is deeply embedded in time (Feinman 2017, p. 48; Knappett 2017 , p. 30). At the same time, 'globalization is one of the most potent theoretical frameworks, for it provides a means by which we can make sense of our socio-cultural connectivities, and the networks through which those connections are developed and maintained' (Hodos 2017, p. 3; Knappett 2017, pp. 30-31; Robertson 2017, p. 54). While 'global' is less important than the idea of 'complex connectivity' and network more than globalization, they (connectivity and network) allow us to model and analyze data (Knappett 2017, p. 29). An important property of globalization is that it is uneven and unsymmetrical in terms of space, scope, and impact (Hodos 2017, p. 4). The key feature of globalization is the spread of a sense of one-placeness in the areas it covers. In the past this was achieved more effectively by shared practices. Another characteristic feature of globalization is the increase in sensitivity to cultural differences among people. The paradox is that there is a balance in globalization between shared practices that bind and the diversities that distinguish participants (Hodos 2017, p. 6). Globalization connects localities, although not equally or simultaneously. The result is not homogeneity but diverse complex and reflexive interactions (Robertson 2017, pp. 54-55).

As part of the globalization process there are various, sometimes seemingly contradictory trends, which are discernible at the level of cultural studies: time-space compression, de-territorialisation, standardisation, unevenness, homogenisation, heterogeneity, the re-embedding of local culture, and vulnerability (Jennings 2017, pp. 14-16). However, hybridisation plays the most important role in the cultural blending process (Rowe, Schelling 1991; Hodos 2017, pp. 5-6). 'Globalization allows archaeologists to move beyond the superficialities of imagined homogenous and hegemonic cultures and civilisations' (Robertson 2017, p. 55).

\section{CULTURAL ANALYSIS}

A different theoretical approach will be used to observe crisis and conflict phenomena from a microregional perspective. Among the many possible ways of interpreting the remains of material culture in terms of palaeosociology, Robert Wuthnow's theory of cultural analysis (Wuthnow 1987) seems to be one of the most effective (Kadrow 2016). It enables the identification of crisis situations, usually accompanied by violence, the effect of which is a change in culture or culture change.

Wuthnow proposed a dynamic model of cultural structure, which names moral order as a central point and which primarily consists of ritual and ideology, symbols and institutions. Mutual interactions and the relationship between these elements of cultural structure determine the dynamics of moral order and, simultaneously, culture itself and social structure (Wuthnow 1987). The functioning of rituals and symbols (but not their meaning) is directly accessible for archaeological observation. Furthermore, ideology and social institutions are indirectly available for archaeological knowledge because they are related to the functioning of symbols and rituals, as has already been mentioned.

The diversity and intensification of ritual practices is an indicator of increasing uncertainty in a community. In turn, uncertainty is a symptom of a crisis situation while rituals (archaeologically observable) are designed to reduce uncertainty and restore social stability. Thus, they constitute archaeologically clear symptoms of social crisis, ones which can usually be accompanied by various forms of violence. Armed conflicts occur especially 
in situations of deepening uncertainty, when ritual practices are unable to remedy them.

Many theories posit that the outbreak of conflict results from uncertainty and a disruption of moral order (Wuthnow 1987), also called a dysfunction of the social system (Johnson 1982). The source of some of them could be external military pressure or aggression, sometimes only the infiltration of foreign people. However, these are necessary but insufficient conditions for conflict (rebellion, revolution, violence etc.) to break out. Another necessary condition is the rise of a charismatic leader (Johnson 1982; Weber 2002) who owes his power to personal charisma.

The sources of social conflict usually lie within the community. The primary reason for sociocultural dynamics (conflicts, changes) is a gap between the program and the actual implementation of moral order. In other words, social conflicts are caused by the 'natural' differences between practice and theory in social life, i.e. between the system of accepted norms and its everyday implementation.

\section{THE LINEAR BAND POTTERY CULTURE IN THE LIGHT OF GLOBALIZATION PROCESSES}

In the second half of $6^{\text {th }}$ millennium $\mathrm{BC}$, during the period of the LBK's development, the entire area of its range was in a state of functioning, lively, mutual contacts that connected all of this culture's communities. Intensive information exchange networks operated at many levels. This is demonstrated by, among other things, the amazing stylistic uniformity of the ceramics in the pre-music note (early) phase and, above all, in the music note (classical) phase from the Paris Basin in the west to the vicinity of Kiev in the east and from the Baltic in the north to the river Drava in the south. Even more extensive was the presence of ornaments made of spondylus shells (Fig. 1), as this added the Balkans, the Aegean, the Adriatic, and Liguria to the range (Müller 1997; Windler 2018, Fig. 5.3). The habit of using and depositing spondylus ornaments is confirmed at the same time throughout the LBK and among other cultures: Alföld Linear Pottery culture (hereafter: ALPC), Vinča, Boian, Karanovo, Dimini, Danilo, impresso, Finale, etc. (Windler 2018, Fig. 5.6). This indicates the existence at the time of a network of socio-cultural and economic connections covering almost the entire continent.

The area of the occurrence of obsidian products mined on the Hungarian-Slovak border is somewhat smaller, although still very extensive (Fig. 2). It includes (not counting incidental occurrences in other areas) the Carpathian Basin, Transylvania, Pannonia, south-western Slovakia, Bohemia and Moravia, southern Poland, and central Germany (Burgert et al. 2017; see also Kadrow 2020a, Fig. 5). This area includes the western and eastern LBK groups, all of the ALPC, and the Vinča and Boian cultures.

Ceramics produced in the northern part of the Carpathian Basin by the Bükk culture communities and other ALPC cultural groups in the areas north of the Carpathians also had a considerable spatial range (Fig. 3). These imports are concentrated around Kraków (Kaczanowska, Godłowska 2009), Rzeszów (Kadrow, Rauba-Bukowska 2017), and Sandomierz (Szeliga, Zakościelna 2019). They are occasionally also found in Silesia, Kujawy, and the Dniester basin in Ukraine (Dębiec 2012). However, the reverse process, i.e. the penetration of LBK ceramics into ALPC areas, is mostly not recorded (cf. Virág 2009, Fig. 6).

Due to the Neolithisation processes, which are described in this article and cover south-eastern Poland (Lesser Poland), the connection networks, as determined by the distribution of some flints extracted in this part of Poland, are also important. This concerns the export of Turonian (Szeliga 2014) and Jurassic flints to the northern part of the Carpathian Basin and neighbouring areas (Mateiciuciová 2008). They cover smaller areas than 


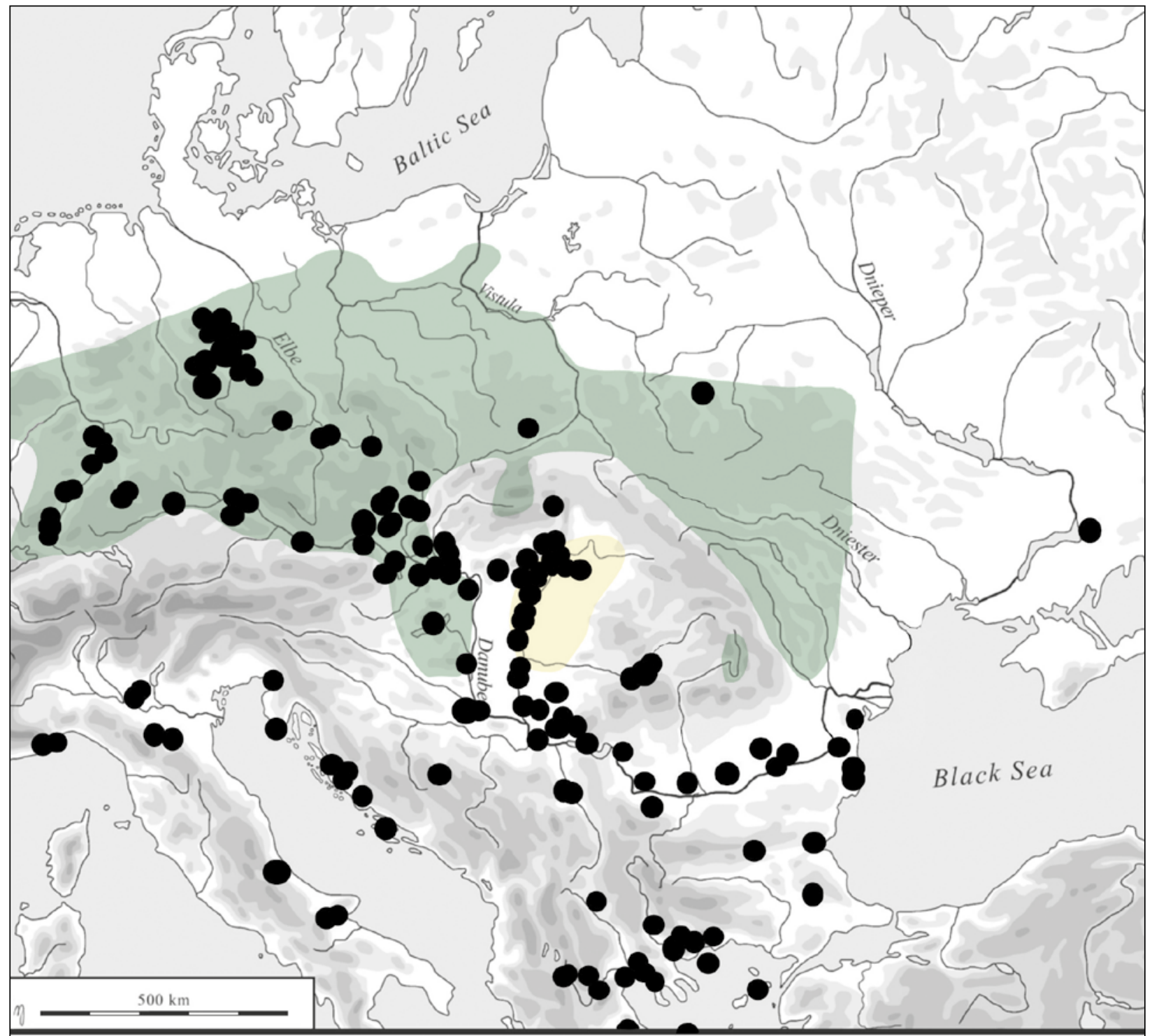

-A $\quad-B \quad$ - - C

Fig. 1. Distribution of spondylus ornaments (C) against the background of the LBK (A) and ALPC (B) territorial ranges (after Windler 2018) as a material trace of connectivity in the early Neolithic in Europe. Drawing by A. Krzywda.

those mentioned above, but also testify to transCarpathian and transcultural contacts between the LBK and ALPC communities.

The spread of anthropomorphic plastic specimens (Pavúk 1969; Becker et al. 2018), including facial imaginations, was also transcultural and at least Central European in nature (Virág 2009, Fig. 6).
Another case of transcultural contacts in the late phase of the LBK is the wide distribution of the custom of decorating the inner walls of vessels (Pavúk 1969, Fig. 30:2).

The abovementioned cases (although, of course, not all of them) argue that the entire LBK area and neighbouring areas, with particular emphasis on 


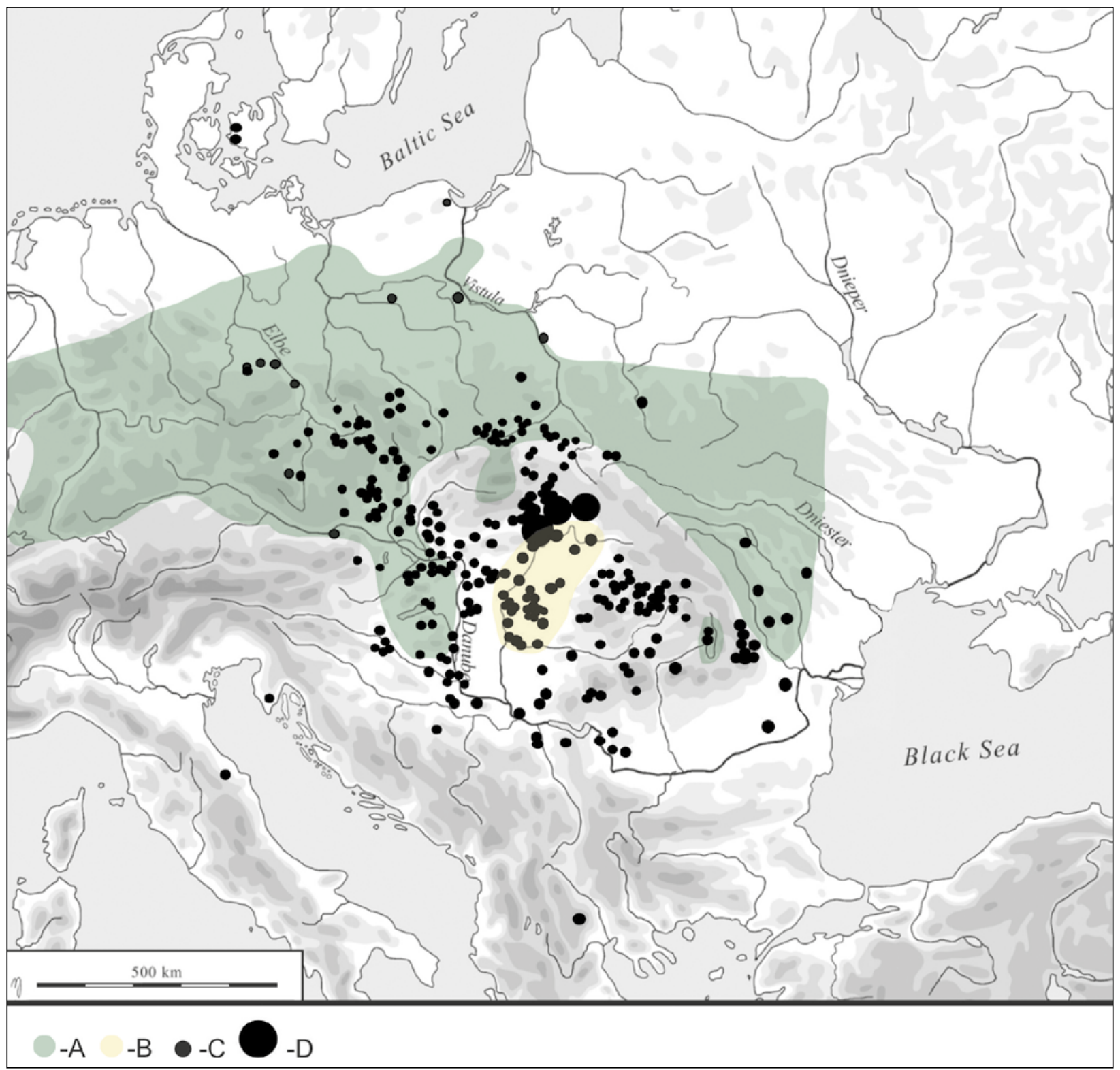

Fig. 2. European distribution of obsidian (C) and places of its exploitation (D) against the background of the LBK (A) and ALPC (B) territorial ranges (after Burgert et al. 2017) as a material trace of connectivity in the early Neolithic in Europe. Drawing by A. Krzywda.

the Carpathian Basin and the Balkans (see Figs. 1 and 2), are characterised by a network of dense connections and information flow (connectivity). Recently published studies on the Neolithisation of Polish territories (Kozłowski, Nowak 2019) show particularly dense networks of mutual contacts between Mesolithic communities and the networks of contacts and expansion directions of the early groups of farmers (Fig. 4).

Despite the close and long-lasting neighbourhood and the possibility of the mutual establishment of various contacts, the Mesolithic and LBK communities in Poland lived in a state of socalled splendid isolation and they made almost no 


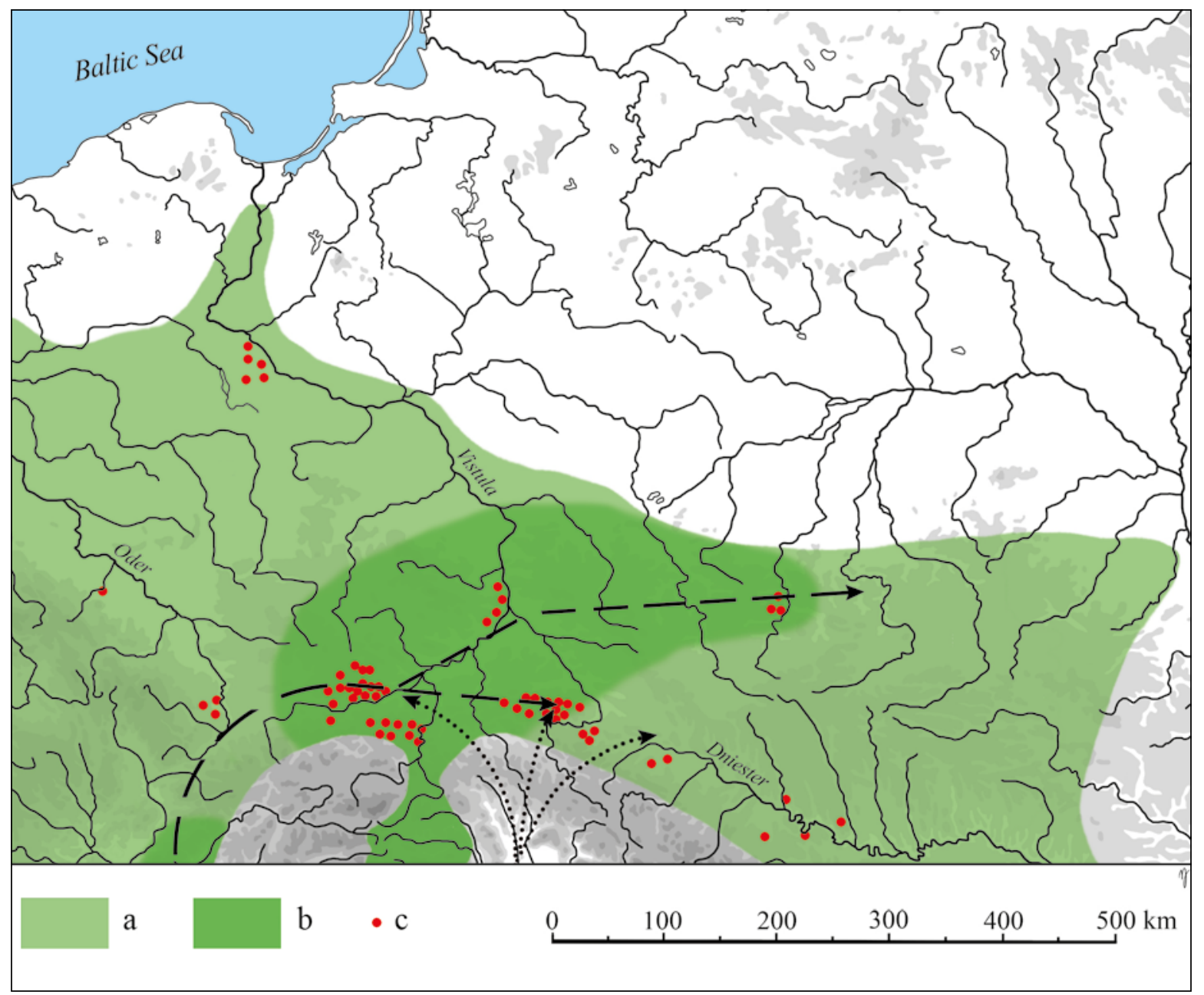

Fig. 3. Distribution of ALPC pottery imports (c) north of the Carpathians showing the directions of cultural influences against the background of the LBK (a) and Želiezovce style territorial ranges (after Kadrow, Rauba-Bukowska 2017). Drawing by I. Jordan.

contact (Kozłowski, Nowak 2019, p. 264). A similar situation prevailed regarding contacts with people from other Neolithic cultural units in Europe. A state of almost total isolation from other cultures characterised the LBK community in its early and music note phase (excluding the distribution of spondylus ornaments). The exchange of stone raw materials (obsidian and flint from Lesser Poland)

Fig. 4. The Rzeszów (A), Kraków (B), and Sandomierz (C) early Neolithic regions against the background of the Mesolithic (black lines) and LBK (red bands) networks of contacts (after Kozłowski, Nowak 2019). Drawing by S. K. Kozłowski and M. Nowak.

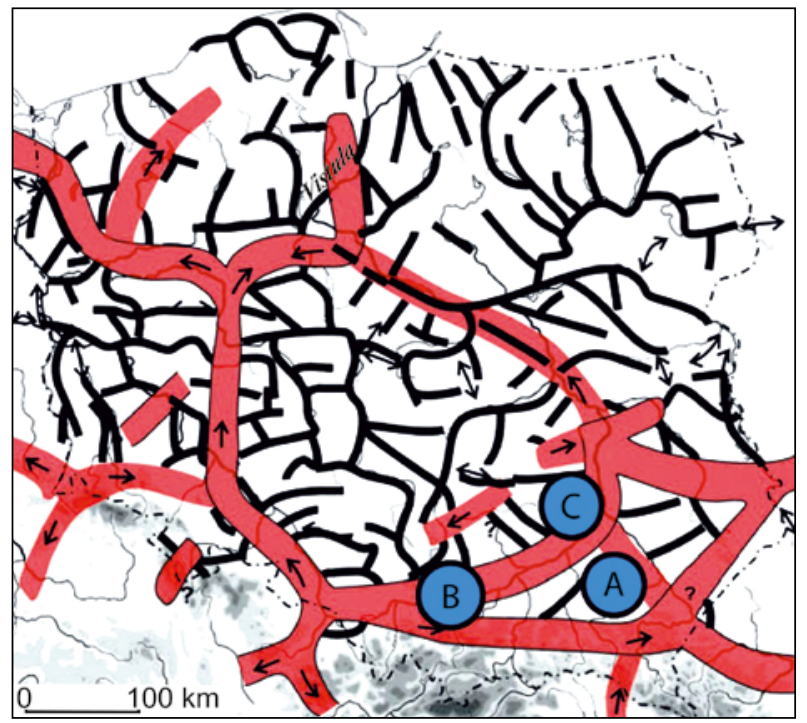




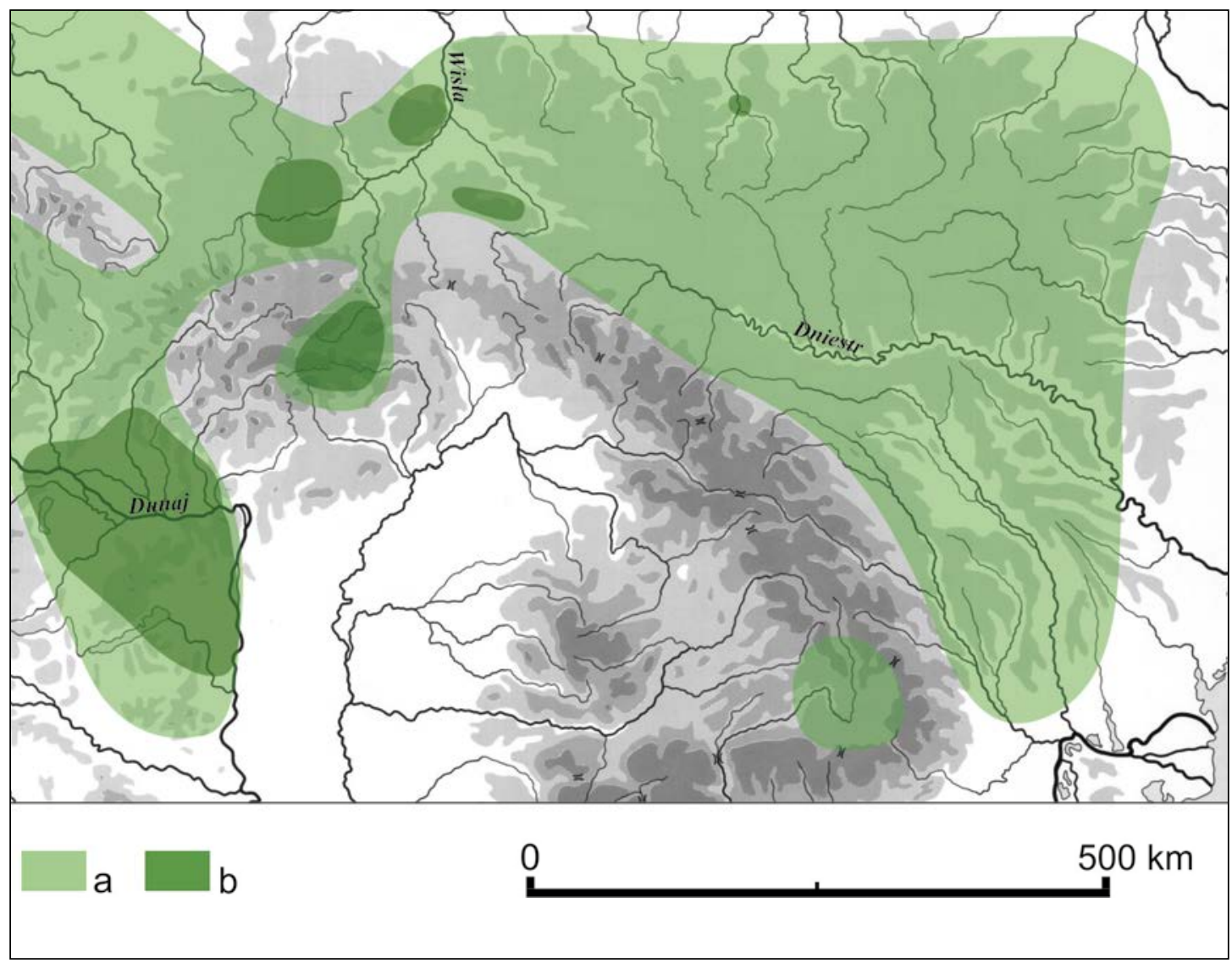

Fig. 5. Insular distribution of the Želiezovce style (b) against the background of the LBK (a) territorial range. Drawing by A. Krzywda.

was sporadic only then. In the areas north of the Carpathians, there were also few imports of ceramics from the ALPC at this time. This stage of the globalization process was characterised by a definite predominance of the standardisation and homogenisation (Jennings 2017, pp. 14-15) of the cultural behaviour (ceramic production, dwelling construction, settlement patterns, and subsistence strategies) between the LBK communities throughout its territorial range.

A definite change in contacts with the population of other Neolithic cultures occurred at the end of the classic phase of the LBK and at the turn of the late phase. There was still no breakthrough in contacts with the Mesolithic population. In south-western Slovakia and in the neighbouring areas of northern Pannonia, the Želiezovce group emerged from the late classical (late music note) phase of the LBK (Pavúk 1969).

An archaeologically perceptible manifestation of this can be seen in the predomination of new rules for the technology of making and decorating ceramics. The clay was usually well prepared and the use of organic temper was abandoned. In terms of ornamentation, a new element was the supply of engraved lines with groups of music notes that were heralds of the Želiezovce style. In addition, the bands between the engraved lines were often smoothed (Pavúk 1969, Fig. 6:2, 5). Sometimes these bands were covered with red paint, red incrustations having been found in the engraved lines. Equally typical was the smoothing of multiple engraved lines on a wet surface before firing (Pavúk 1969, Fig. 10:25). Such innovations were accompanied by imports and 
imitations of ceramics from the ALPC area (Pavúk 1969, p. 275).

For unspecified reasons, there was then an acceleration and intensification of the interactions with the South-East of Europe, from the area of the Neolithic Balkan cultures, mainly from the Vinča culture through the Szakalhat group, which is part of the ALPC complex (Pavúk 1969, pp. 338-352). A phenomenon typical for globalization processes took place at that time, i.e. time-space compression, involving the acceleration of long-range contacts (Jennings 2017, p. 14).

Shortly after the crystallisation of the Želiezovce group, its style of pottery ornamentation was diffused throughout northern Pannonia, Lesser Poland, and Volhynia (Fig. 5). Territorially, the largest agglomeration of the Želiezovce style in Lesser Poland was in the Kraków region, which includes the Rudawa, Dłubnia, Szreniawa, and Nidzica river basins and the Nowa Huta section of the Vistula along with the Wieliczka-Bochnia loess forelands (Czekaj-Zastawny 2008, Fig. 68; Kaczanowska, Godłowska 2009, Fig. 1). Part of this agglomeration also probably includes the areas around Łoniowa (Valde-Nowak 2013, Fig. 3) and Gwoździec (CzekajZastawny et al. 2020).

The second largest area in terms of its saturation with Želiezovce elements is the Rzeszów region, whose eastern end reaches the Przeworsk and Jarosław areas (see Kadrow 2013; Kadrow, Sznajdrowska 2013). Only a few isolated fragments of pottery decorated in the Želiezovce style come from the Przemyśl area (Czekaj-Zastawny 2008, pp. 223-225) as well as from several sites in the Dniester basin (Dębiec 2012). The agglomeration in the Sandomierz Upland is quite large, but less well recognised (KowalewskaMarszałek 1992; Szeliga, Zakościelna 2019). The last and smallest agglomeration of ceramics in the Želiezovce style (associated with south-eastern Poland) is in Volhynia, in the vicinity of Rivne (e.g. Bardetskiy 2012; Dębiec 2012).
The Želiezovce agglomerations north of the Carpathians are insular (Fig. 5). This suggests their synchronism with the LBK assemblages from the surrounding areas where there are not many ceramics and where the pottery, which does feature stylistic similarities, still belongs to the music note phase. It seems that the Želiezovce style was not adopted by the communities of all the LBK regions of Lesser Poland, even those that were closely adjacent to one another. It seems quite probable, considering that the residents of some houses in the same settlement accepted foreign designs and products (imports of ALPC ceramics and obsidian), while at the same time others displayed no interest in it. This phenomenon was well documented at site 17 in Brzezie (CzekajZastawny 2014, Fig. 46). Perhaps a similar situation occurred at site 16 in Rzeszów, where there are imports of ALPC ceramics and obsidian in some assemblages dated to the late phase, while others completely lack such remains (Kadrow 1990a, Fig. 26; Kadrow 1990b, pp. 59-63, Fig. 17).

Thus, a typical situation of the late phase within the eastern LBK was the co-occurrence of 'progressive' phenomena in the form of the Želiezovce group in South-Western Slovakia, northern Transdanubia, and neighbouring Austria with the 'conservative' Kesztehly group in South-Western Hungary, corresponding stylistically to the music note phase (Marton, Oross 2009, table 1).

Similarly, in the areas north and east of the arch of the Carpathians, i.e. in Lesser Poland and Volhynia, there were ensembles with pottery ornamented in the Želiezovce style which existed alongside the ongoing conservative music note groups in other areas, e.g. in the Lublin region and the Dniester river basin (Pavúk 1969, p. 270; Kozłowski 1985; Dębiec 2012).

This revealed the phenomenon of unevenness between regions and de-territorialisation so typical of the globalization process, in which people living in the distant progressive settlements of the Želiezovce group/phase in the vicinity of Kraków and Rzeszów 
had more in common than they did with residents of nearby conservative sites (dated to the music note phase) (Jennings 2017, pp. 14-15).

Beginning with the end of the music note phase until the end of the Želiezovce phase, the inflow of imported ALPC ceramics from the Tisza basin and obsidian from the northern part of the Carpathian Basin is observed in the Kraków, Rzeszów, and Sandomierz settlement centres (Kadrow 2020a, pp. 92-95; Figs. 4, 5). This was accompanied by a process of change in the technology of making ceramic vessels. The percentage of organic temper in the ceramic mass decreased and at the same time the percentage of grog (chamotte) increased (Kadrow 2020a, pp. 91-92, Fig. 2, 8). LBK ceramic production technology became closer to ALPC technology (Rauba-Bukowska 2014). The importers were mainly residents of houses producing and using ceramics decorated in the Želiezovce style (Kadrow 1990b, pp. 54-58, Fig. 14).

At the level of the progressive houses, settlements, and settlement regions, the phenomenon of heterogeneity, again so characteristic of globalization, took place. Its archaeological remains are shown by the ceramic inventories, in which the music note, Želiezovce, and ALPC circle style coexisted. It occurred because cultural variation increased in the late phase of the LBK, despite some homogenisation, which had dominated in earlier periods. In the other areas, the homogenisation continued in the style of the music note phase.

However, it is difficult to archaeologically detect the phenomenon of the 're-embedding of local culture' which is caused by communities who react to global flows of ideas, objects, and people by attempting to reassert local traditions (Jennings 2017, p. 15). Traces of this phenomenon perhaps include settlement complexes exhibiting the dominant face of the music note phase with few imports or imitations of ALPC ceramics. They were probably those communities in the Dniester and Prut basins, in which the heterogenisation processes had begun but had been unsuccessful.

The effect of the multiplication of crisis situations, so typical among others for the late LBK in the western part of Europe, was a culture change (Jeunesse 2009, pp. 167-171). In the terminology of globalization, it is possible to talk about the phenomenon of vulnerability, as opposed to connectivity, the essence of which was the collapse of the interaction networks (Jennings 2017, p. 16) and the initial preparation for culture change.

\section{THE EARLY NEOLITHIC IN THE RZESZÓW MICROREGION IN THE LIGHT OF CULTURAL ANALYSIS}

Parallel to the technological innovations in LBK ceramics, the intensification of the importation of ALPC pottery and the phenomenon of the local imitation of this pottery by people living in areas north of the Carpathians can be observed. This pottery was frequently imported at the end of the LBK development, during the reign of the Želiezovce style in ceramics.

Participation in the propagation of the Želiezovce ceramic style and the import of ALPC ceramics and obsidian was attended by populations living primarily in the Rzeszów, Kraków, and Sandomierz regions (Fig. 3), and in them only by residents of some settlements and some long houses (Kadrow 2020a, p. 98; Figs. 4, 5).

In the Rzeszów region (Fig. 6), a rapid demographic development of the local population was found at the end of the LBK development (Fig. 7). It is related to the period of the intensification of the inflow of imports from behind the Carpathians and the heyday of the Želiezovce style in ceramics. Later, this upward demographic trend was more subdued and was accompanied by a culture change, discernible in the replacement of the style of ceramics typical of late LBK by the style of Malice culture 


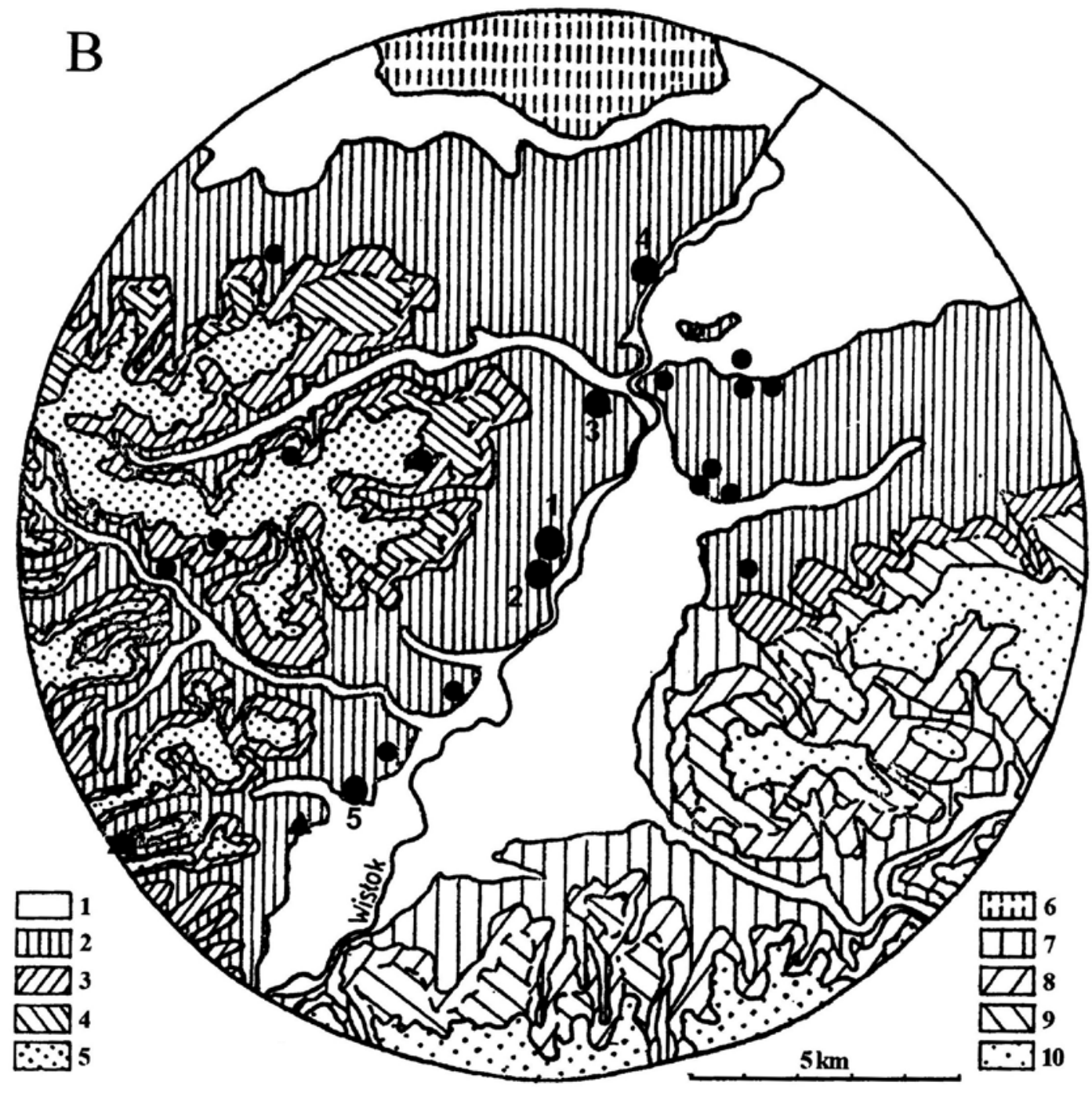

Fig. 6. The Rzeszów region of early Neolithic settlements against the background of the arrangement of landscape zones typical for SE Poland; legend: 1 - bottom of a river valley, 2 - on a floodplain loess terrace; 3-5 - higher landscape zones with loess cover; 6-10 - higher landscape zones without loess cover; black circles - early Neolithic sites including: 1 - Rzeszów, site 16; 2 - Rzeszów, site 20; 3 - Rzeszów, site 3; 4 - Rzeszów, site 34; and 5 - Zwięczyca, site 3 (after Kadrow 2020a). Drawing by S. Kadrow.

ceramics. The sudden change in pottery style was accompanied by the disappearance of imports of ceramics from the Carpathian Basin and an abrupt change in the house construction methods. The size of settlements and settlement zones decreased significantly (Kadrow 2020a, p. 98, Fig. 7).

At the same time, however, the continuation of the trend of technological changes in ceramics production is observed together with the continuation of obsidian inflow (Kadrow 2020a, p. 99; Fig. 6). It seems that the basic subsistence strategies were still being used.

Apart from the penetration of the Rzeszów region in the older, pre-music-note phase (I) of the LBK, permanent settlement of this area took place at the beginning of the classical phase. Settlers produced ceramics in the early stage of the music-note style (II) and built longhouses and inhabited permanent 


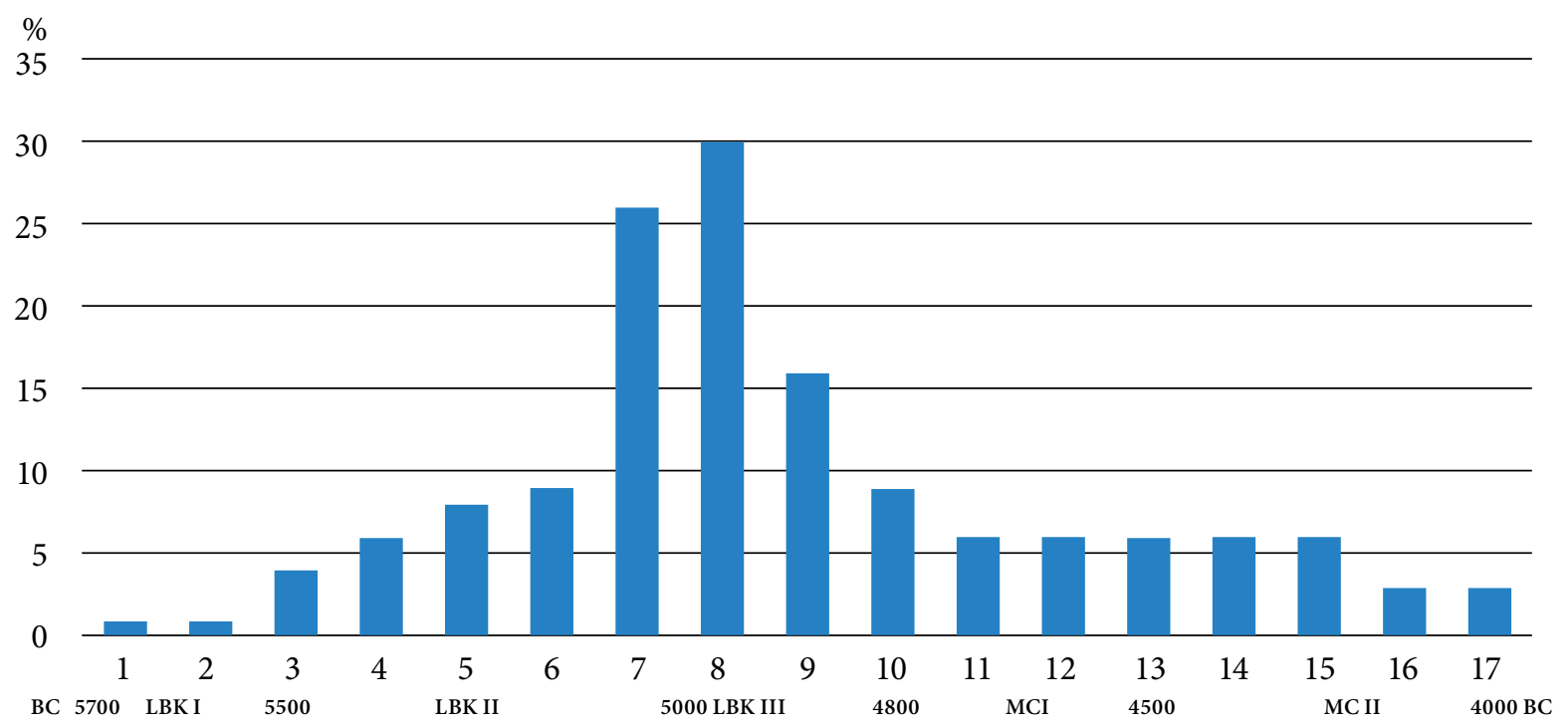

Fig. 7. Dynamics of the demographic changes in the Rzeszów microregion during the LBK and the evolution of the MC (for details, see Kadrow 1990a). Drawing by S. Kadrow.

settlements. Stone tools were made of Jurassic flint, imported from the Krakow area. This period is characterised by the uniformity (homogenisation) of the material culture and settlement strategies, typical for the entire eastern zone of LBK in its European range. There is no evidence of systematic contact with the local Mesolithic population or more vivid links with their neighbours (ALPC) from beyond the Carpathians.

In light of Robert Wuthnow's (1987) theory of cultural analysis, this was a period of the perfect compliance of the norms with the practice in an integrated, closed community. 'Certainty' reigned (the opposite of the key concept in this theory of 'uncertainty', characteristic of periods of conflict), which is typical of periods of social and culture stabilisation.

In the middle stage of the music-note phase (II) of the LBK, more cases of the importation of obsidian and ALPC ceramics (Fig. 3) are seen for the first time. Not all of the inhabitants of the Rzeszów region participated in importing foreign products, raw materials and imported artefacts having been registered in just some settlements.
Only some long-houses contain such specimens in these settlements. The process of the opening up of local communities to external influences and impacts can be traced to this period. At the same time, the process of the progressive internal differentiation of the described communities can be seen. In addition to conservative groups who adhered to local traditions, there were also groups (importers of obsidian and ALPC pottery) oriented towards external contact (Kadrow 2020a, p. 100). The abovementioned phenomena are accompanied by an (initially slow) increase in the population of the Rzeszów region (Fig. 7).

Later these processes accelerated, continuing at the end of the music-note phase (II) of the LBK. However, they were particularly intense during the Želiezovce phase (III). At the same time, this was accompanied by changes in the technology of ceramic mass preparation for the production of LBK pottery, which slowly but consistently brought it closer to ALPC ceramic technology (Rauba-Bukowska 2014).

The intensification, over time, of ritual activities among the LBK community in the Rzeszów region, proven inter alia by the proliferation of competing 
styles of ceramic ornamentation (music-note, Želiezovce, and ALPC), is proof of a growing uncertainty, i.e. a situation of increased social conflict (Wuthnow 1987). The rivalry of some groups in the Rzeszów region is manifested by the adoption of various competing ideologies, which are mirrored in related rituals and symbols. Different groups referred to different traditions (rooted in music-note, Želiezovce, and ALPC stylistics).

The inflow of new population groups (families) from the vicinity of Kraków was probably responsible for the significant increase in population size at the beginning of the Želiezovce phase (III) of the LBK in the Rzeszów region (Fig. 7), as evidenced by the strong stylistic relationships of the ceramics from both regions. An increase in the local population at such a rapid rate was not possible in the reality of the early Neolithic (see Piasecki 1990; Kadrow 2020a, p. 100).

An increase in the intensity of the ritual activities, along with a simultaneous increase in population size (Fig. 7), is a typical symptom of acute conflict within communities living in the Rzeszów region, growing from the middle stage of the music-note phase (II) and culminating in the beginning of the Želiezovce phase (III) of the LBK. Its effect was a cultural change and the LBK gave way to the MC. It consisted of a fairly sudden change in these aspects of material culture, which had a symbolic significance for the people of that time, above all in the forms and ornamentation of ceramics, changes in the raw material of the stone industry (the replacement of Jurassic flint with chocolate flint), and the construction methods and sizes of the houses (Kadrow 2020a, p. 100).

Other elements typical for the LBK (obsidian import, strategies of settling the same landscape zones in the loess areas) were still continued in the new MC system. Most importantly, from the perspective of the points mentioned in this article, the process of changes (innovations) in ceramic technology continued, mainly based on the elimination of organic temper from ceramic masses and its replacement with grog (Kadrow 2020a, p. 101).

\section{CONCLUSIONS}

Recently, the history and assessment of the state of research on the Neolithisation of Polish areas has been reviewed several times (e.g. Nowak 2009; Kadrow 2019; Kozłowski, Nowak 2019 etc.). Currently, the prevailing view is that in the middle of the $6^{\text {th }}$ millennium $\mathrm{BC}$ the Polish territories were inhabited by a population from four Mesolithic cultures: Komornice, Chojnice-Pieńki, Janisławice, and Kunda. At the beginning of the second half of the $6^{\text {th }}$ millennium, from the south, mainly through the Moravian Gate, the first groups of the oldest farmers representing the LBK began to flow in. They went to Silesia, Lesser Poland, and to the north, reaching their maximum territorial range in about 150 years (Kozłowski, Nowak 2019, pp. 261-262).

During the development of the LBK, there was considerable cultural uniformity in the areas of south-western Slovakia and Lesser Poland. This was caused by the persistence of intense interpersonal contacts between the starting migration area (SW Slovakia) and the colonised areas (Lesser Poland). The weakening of these ties at the end of the LBK was to become the reason for the disappearance of the aforementioned cultural unification (Kozłowski, Nowak 2019, p. 262).

For a long period during the domination of the Danube cultures in Poland, i.e. from 5500 to 4200 $\mathrm{BC}$, the close proximity and mutual contacts of the Mesolithic and Neolithic communities did not trigger acculturation processes (Kozłowski, Nowak 2019, p. 264).

The above conclusions were formulated without referring to the theory of socio-cultural process. This article aims to include this issue in the discussion of Neolithisation processes. 
As mentioned in the introduction, the selected analytical tools (globalization and cultural analysis) are not intended to replace the previously and currently used methods for studying Neolithisation processes, but to supplement them. These are not the only tools, but some of the many possible. They show that the study of the complex process of Neolithisation cannot be limited to a search for one decisive mechanism, or only one cause. Studies of these issues should aim to distinguish the factors and phenomena, which comprise the real cause-effect relationships, from truly random time-space correlations, regardless of whether they are local or supra-regional.

This article is an attempt to draw attention to the need to build a bridge between the activities of a socialised individual (habitus), through intermediate stages (e.g. local conflicts), to the globalization processes of various ranges.

\section{Acknowledgments}

This article has benefited from financial support afforded by Polish National Science Centre NCN 2016/21/B/HS3/03137.

\section{REFERENCES}

Bardetskiy, A., 2012. New Materials from the Excavations of a Multi-Period Settlement of Rovantsi, Hnidavska Hirka (Lutsk Raion, Volhynia Oblast) in 2010. Sprawozdania Archeologiczne, 64, 343-396.

Becker, V., Dębiec, M., Bardetskiy, A. B., 2018. We are one: figural finds from the eastern border of the Linear Pottery Culture distribution. Sprawozdania Archeologiczne, 70, 227-242.

Bourdieu, P., 1972. Esquisse d'une théorie de la pratique: précédé de trois études d'ethnologie kabyle. Genève: Droz.

Burgert, P., Přichystal, A., Prokeš, L., Petřik, J., Huškova, S., 2017. The origin and distribution of obsidian in prehistoric Bohemia. Bulgarian e-Journal of Archaeology, 7(1), 1-15.
Czekaj-Zastawny, A., 2008. Osadnictwo społeczności kultury ceramiki wstęgowej rytej $w$ dorzeczu górnej Wisły. Kraków: Instytut Archeologii i Etnologii PAN.

Czekaj-Zastawny, A., 2014. Brzezie 17. Osada kultury ceramiki wstegowej rytej (=Via Archaeologica, Źródła z badań wykopaliskowych na trasie autostrady A4 w Małopolsce). Kraków: Krakowski Zespół do Badań Autostrad.

Czekaj-Zastawny, A., Rauba-Bukowska, A., Kukułka, A., Kufel-Diakowska, B., Lityńska-Zając, M., Moskal-del Hoyo, M. Wilczyński, J., 2020. The earliest farming communities north of the Carpathians: The settlement at Gwoździec site 2. PLoS ONE, 15(1), e0227008. https://doi.org/10.1371/journal.pone.0227008.

Dębiec, M., 2012. Kultura ceramiki wstęgowej rytej na Ukrainie. Rzeszów (typescript of $\mathrm{PhD}$ Thesis in the Archives of the Institute of Archaeology, Rzeszów University).

Feinman, G. M., 2017. Economic aspects of globalization in the past material world. In: Hodos, T., ed. The Routledge Handbook of Archaeology and Globalization. London \& New York: Routledge, 42-53.

Giddens, A., 1984. The Constitution of Society. Outline of the Theory of Structuration. Oxford: Blackwell Publishers Ltd.

Hodos, T., 2017. Some basics. An Introduction to the Routledge Handbook of Archaeology and Globalizatiom. In: Hodos, T., ed. The Routledge Handbook of Archaeology and Globalization. London \& New York: Routledge, 3-11.

Jennings, J., 2017. Distinguishing past globalizations. In: Hodos, T., ed. The Routledge Handbook of Archaeology and Globalization. London \& New York: Routledge, 12-28.

Jeunesse, C., 2009. Le front de colonisation occidental (entre Rhin et Seine) et l'identité rubanée. Réflexion sur les systèmes symboliques dans le Néolithique danubien. In: Kozłowski, J. K., ed. Interactions between Different Models of Neolithisation North of 
the Central European Agro-Ecological Barrier (=Prace Komisji Prehistorii Karpat PAU 5). Kraków: Polska Akademia Umiejętności, 151-176.

Johnson, C., 1982. Revolutionary Change. Stanford University Press.

Kaczanowska, M., Godłowska, M., 2009. Contacts between the Eastern and Western Linear Cultures in South-Eastern Poland. In: Kozłowski, J. K., ed. Interactions between Different Models of Neolithisation North of the Central European Agro-Ecological Barrier (=Prace Komisji Prehistorii Karpat PAU 5). Kraków: Polska Akademia Umiejętności, 137-149.

Kadrow, S., 1990a. Osada neolityczna na stan. nr 16 w Rzeszowie na osiedlu Piastów. Sprawozdania Archeologiczne, 41, 9-76.

Kadrow, S.,1990b. The Rzeszów Settlement Microregion in Neolithic. Acta Archaeologica Carpathica, 29, 33-70.

Kadrow, S. 2013. Kultura ceramiki wstęgowej rytej. In: Mazurek, M., ed. Opracowanie ratowniczych badań wykopaliskowych na stanowisku 42 (a4/8) w Rozborzu gm. Przeworsk. Rzeszów (typescript in the archives of Fundacja Rzeszowskiego Ośrodka Archeologicznego).

Kadrow, S., 2016. Ritual, Meaning and Moral Order. Social and Symbolic Significance of Copper Artifacts. A Case Study of an Early Eneolithic Settlement in Poland. In: Ursu, C.-E., ed. Between Earth and Heaven. From Symbols to Signs, In Memory of Henrieta Todorova (=Ethnoreligion Series 2). Suceava: Editura Karl. A. Romstorfer, 107-124.

Kadrow, S., 2019. The Process of Neolithisation in South-Eastern Poland - Selected Problems. Archaeologia Polona, 57, 35-45.

Kadrow, S., 2020a. Innovations in ceramic technology in the context of culture change north of the Carpathians at the turn of the $6^{\text {th }}$ and $5^{\text {th }}$ millennia BCE. In: Furholt, M., Spataro, M., eds. Detecting and explaining technological innovation in prehistory (= Scales of transformation 8$)$. Leiden: Sidestone Press, 85-105.
Kadrow, S., 2020b. Social Organization and Change. In: Gardner, A., Lake, M., Sommer, U., eds. The Oxford Handbook of Archaeological Theory. Oxford University Press, 1-22. https://doi.org/10.1093/ oxfordhb/9780199567942.013.023.

Kadrow, S., Müller, J., 2019. Habitus? The social dimension of technology and transformation - an introduction. In: Kadrow, S., Müller, J., eds. Habitus? The social dimension of technology and transformation (=Scales of Transformation 3). Leiden: Sidestone Press, $11-14$.

Kadrow, S., Rauba-Bukowska, A., 2017. The selection of ceramic raw material: convenience or a technological idea? A case study of the Danubian cultures north of the Carpathians. Archeologické rozhledy, 69, 261-280.

Kadrow, S., Sznajdrowska, A., 2013. Krąg kultur naddunajskich. In: Mazurek, M., ed. Opracowanie Ratowniczych Badań Wykopaliskowych na Stanowisku 28 (A4/9) w Rozborzu gm. Przeworsk, Rzeszów (typescript in the archives of Fundacja Rzeszowskiego Ośrodka Archeologicznego).

Knappett, C., 2017. Globalization, connectivities and networks. In: Hodos, T., ed. The Routledge Handbook of Archaeology and Globalization. London \& New York: Routledge, 29-41.

Kowalewska-Marszałek, H., 1992. Osadnictwo neolityczne na Wyżynie Sandomierskiej. Warszawa (typescript of $\mathrm{PhD}$ thesis in the archives of Institute of Archaeology and Ethnology, Polish Academy of Sciences).

Kozłowski, J. K., 1985. The eastern areas of the Linear Band Pottery culture. In: Kokowski, A., ed. Mémoires Archéologiques. Lublin: Wydawnictwo UMCS, 51-70.

Kozłowski, S. K., Nowak, M., 2019. I przyszli ludzie zza Gór Wysokich. Ziemie polskie od VI do IV tysiąclecia вС (=Collectio Archeologica Ressoviensis 39). Rzeszów: Instytut Archeologii Uniwersytetu Rzeszowskiego, Ośrodek Badań nad Antykiem Europy Południowo-Wschodniej Uniwersytetu Warszwskiego. 
Marton, T., Oross, K., 2009. Reconstructing Space in a Familiar World: the Formation of Late LBK Settlements in Central Transdanubia. In: Kozłowski, J. K., ed. Interactions between Different Models of Neolithisation North of the Central European Agro-Ecological Barrier (=Prace Komisji Prehistorii Karpat PAU 5). Kraków: Polska Akademia Umiejętności, 51-73.

Mateiciuciová, I., 2008. Talking Stones. The Chipped Stone Industry in Lower Austria and Moravia and the Beginnings of the Neolithic in Central Europe. Brno: Masaryková Univerzita.

Milojčić, V., 1960. Präkeramisches Neolithikum auf der Balkanhalbinsel. Germania, 38, 320-355.

Müller, J., 1997. Neolithische und chalkolithische Spondylusartefakte. Anmerkungen zu Verbreitung, Tauschgebiet und sozialer Funktion. In: Becker, C., Dunkelmann, M. L., Metzner-Nebelsick, C., Peter-Röcher, H., Roeder, M., Teržan, B., eds. Chronos. Beiträge zur prähistorischen Archäologie zwischen Nord- und Südosteuropa. Festschrift für Bernhard Hänsel. Espelkamp: Verlag Marie Leidorf GmbH, 91-106.

Nowak, M., 2009. Drugi etap neolityzacji ziem polskich. Kraków: Księgarnia Akademicka.

Pavúk, J., 1969. Chronologie der ŽeliezovceGruppe. Slovenská Archeológia, 17(2), 269-367.

Piasecki E. 1990. Cmentarzyska w aspekcie demograficznym. Przegląd Archeologiczny, 37, 5-51.

Rauba-Bukowska, A., 2014. Wyniki badań mineralogiczno-petrograficznych naczyń importowanych kręgu wschodniolinearnego, odkrytych na stanowisku Brzezie 17, gm. Kłaj. In: Czekaj-Zastawny, A., ed. Brzezie 17. Osada kultury ceramiki wstegowej rytej. Kraków: Krakowski Zespół do Badań Autostrad, 459-468.

Rimantienè, R., 1979. Šventoji. Narvos kultūros gyvenvietès. Vilnius: Mokslas.

Robertson, R., 2017. Globalization thinking and the past. In: Hodos, T., ed. The Routledge Handbook of Archaeology and Globalization. London \& New York: Routledge, 54-65.

Rowe, W., Schelling, V., 1991. Memory and Modernity: Popular Culture in Latin America. London: Verso Books.

Szeliga, M., 2014. The Distribution and Importance of Turonian Flints from the NorthEastern Margin of the Holy Cross Mountains in the Flint Raw Material Economy of the Earliest Danubian Communities. Acta Archaeologica Carpathica, 49, 77-112.

Szeliga, M., Zakościelna, A., 2019. Transcarpathian Intercultural Relationships of the LBK Communities from the Sandomierz Settlement Cluster in the Light of New Findings. Sprawozdania Archeologiczne, 71, 167-195.

Sztompka, P., 1991. Society in Action: The Theory of Social Becoming. Cambridge: Polity Press.

Sztompka, P., 2007. Socjologia zmian społecznych. Kraków: Znak.

Tomlinson, J., 1991. Cultural Imperialism: A Critical Introduction. Baltimore: Johns Hopkins University Press.

Troskosky, C, B., White, J. M., Gaižauskas, L., 2019. A Unified Model for the Governing Dynamics of Agricultural Frontier Zones. Lietuvos Archeologija, 45, 145-167.

Valde-Nowak, P., 2013. New light on Bandkeramik longhouses. In: Kadrow, S., Włodarczak, P., eds. Environment and Subsistence - forty years after Janusz Kruk's „Settlement studies” Studia nad Pradziejami Europy Środkowej 11. Rzeszów-Bonn: Instytut Archeologii Uniwersytetu Rzeszowskiego \& Dr. Rudolf Habelt, 95-103.

Virág, Z. M., 2009. The Eastern Periphery of the Central European LPC in the Region of Budapest. In: Kozłowski, J. K., ed. Interactions between Different Models of Neolithisation North of the Central European Agro-Ecological Barrier (=Prace Komisji Prehistorii Karpat PAU 5). Kraków: Polska Akademia Umiejętności, 9-30. 
Weber, M., 2002. Gospodarka i społeczeństwo. Zarys socjologii rozumiejącej. Warszawa: PWN.

Windler, A., 2018. Der Austausch von Spondylus gaederopus in Europa zwischen 5500 und 5000 v. Chr. Eine ökonomische Analyse (=Raw Materials, Innovation, Technology of Ancient Cultures 6). Bochum: Verlag Marie Leidorf GmbH.
Wuthnow, R., 1987. Meaning and Moral Order. Explorations in Cultural Analysis. Berkeley: University of California Press.

Zvelebil, M., 2005. Homo habitus: agency, structure and the transformation of tradition in the constitution of the TRB foraging-farming communities in the North European plain (ca 45002000 вс). Documenta Praehistorica, 32, 87-101.

\title{
PIETRYČIŲ LENKIJOS NEOLITIZACIJOS PROCESAI MIKRO- IR MAKROLYGMENIMIS VIDURIO IR RYTŲ EUROPOS KONTEKSTE
}

\author{
Sławomir Kadrow
}

\section{Santrauka}

Šio straipsnio tikslas yra globaliu (makro-) ir vietiniu (mikroregioniniu) lygmenimis apibrèžti pietryčių Lenkijos neolitizacijos proceso priežastis, mechanizmus ir eigą. Viena vertus, makrolygmens procesai efektyviausiai gali būti atliekami vartojant globalizacijos teorijos sąvokas ir nuostatas (Hodos 2017). Kita vertus, remiantis kultūrine analize (Wuthnow 1987) manoma, kad pagrindinè varomoji didžiųjų pokyčių mikromastu jèga yra konfliktas. Globalizacija yra bendruomeniškumo ir tarpusavio ryšių palaikymo forma. Tai yra kaina, kurią žmonès sumoka, norėdami gauti prieigą prie išteklių, reikalingų patenkinti jų statuso ir gerovès troškimui. Taigi žmonès, suvokdami vienas kito ketinimus ir siekius, įsitraukia ị konfliktus, kurie gali tapti viena iš pagrindinių krizès ir kultūrinių pokyčių priežastimi.

Kultūrinès analizès teorija, kurią sukūrè Robertas Wuthnow (1987), leidžia nustatyti krizines situacijas (paprastai lydimas smurto), nulèmusias kultūrinius pokyčius arba kultūros permainas.

Antroje VI tūkstantmečio pr. Kr. pusëje, tai yra vystantis Juostinès linijinès keramikos (toliau - JLK) kultūrai, visoje jos išplitimo teritorijoje veikẻ gyvybingi tarpusavio ryšiai, jungiantys visas šios kultūros bendruomenes.

Intensyvūs informacijos mainų tinklai veikè daugeliu lygių; vienas iš pavyzdžių yra stilistinis keramikos vientisumas ankstyvajame (prieš natų ornamento atsiradimą) ir ypač klasikiniame (natų ornamento gyvavimo) laikotarpyje.

Dar plačiau buvo paplitę spondilų kriauklių papuošalai (1 pav.). Vengrijos ir Slovakijos pasienyje išgauto obsidiano gaminių paplitimo teritorija buvo šiek tiek mažesnè (2 pav.).

Atsižvelgiant i i išvardytus pavyzdžius, teigiama, kad visa JLK kultūros teritorija ir kaimyninès žemès (ypatingą dèmesị skiriant Balkanams ir Karpatų lygumai) pasižymèjo kaip glaudžių ryšių ir informacijos srauto tinklas.

Aiškūs pasikeitimai kontaktuose tarp kitų neolitinių kultūrų vyko JLK kultūros klasikinio laikotarpio pabaigoje ir vèlyvojo laikotarpio pradžioje. Iš vėlyvosios JLK kultūros išsivystė Želiezovce kultūrinė grupé, paplitusi pietvakarių Slovakijoje ir kaimyninėse šiaurinès Panonijos teritorijose (Pavúk 1969). 
Neilgai trukus, šiai kultūrai būdingas keramikos stilius pasklido po visą šiaurinę Panoniją, Mažąją Lenkiją ir Voluinę (5 pav.).

JLK kultūros grupès bendruomenès, gyvenusios Mažojoje Lenkijoje, neperėmė Želiezovce kultūros stiliaus, nors ir gyveno visai šalia. Šis pavyzdys atskleidžia regionų skirtumus ir deteritorizacijos reiškinị, būdingą globalizacijos procesui. Jam vykstant, žmonès, gyvenantys tolimose progresyviose Želiezovce grupès/etapo gyvenvietėse netoli Krokuvos ir Žešuvo, tarpusavyje turejjo daugiau bendro nei su netoliese gyvenančiais žmonèmis (vietovėse, datuojamose natų ornamento etapu).

Rytinès juostinès linijinès keramikos iš Tisos baseino teritorijos ir obsidiano iš šiaurinès Karpatų lygumos dalies importo srautai buvo identifikuoti pietryčių Lenkijoje ir datuoti laikotarpiu nuo natų ornamento etapo pabaigos iki pat Želiezovce etapo pabaigos. Su importo srautais buvo pastebèti ir keramikos gamybos technologijos pokyčiai. Pažangių namų, gyvenviečių ir apgyvendintų regionų lygmenyje pasireiškè nevienalytiškumas, taip pat labai būdingas globalizacijai. Archeologinè medžiaga - keramikos radinių inventoriai - yra to i̇rodymas, kai randama vienu metu egzistuojantys natų ornamento, Želiezovce ir apskritimų ant Rytinès JLK kultūros stiliai. Kultūrinè ịvairovè JLK kultūros etape didejo nepaisant ribotos homogenizacijos, vyravusios ankstesniuose laikotarpiuose.

Žešuvo teritorija buvo galutiniai apgyventa klasikinio etapo pradžioje. Gyventojai gamino keramiką, būdingą ankstyvajam natų ornamento stiliui (II), ir statė ilguosius namus. Akmeniniai įrankiai buvo gaminami iš Juros periodo titnago, atsivežto iš Krokuvos apylinkių. Šiam laikotarpiui būdingas materialiosios kultūros ir apgyvenimo strategijų vientisumas (homogeniškumas) pastebimas visoje JLK kultūros teritorijoje, europinèje jos srityje. Pagal R. Wuthnowo (1987) kultūros analizès teoriją, šiame laikotarpyje buvo matomas tobulas normų ir praktikų atitikimas integruotoje, uždaroje bendruomenèje.

Atvežtinio obsidiano ir Rytinès JLK kultūros pavyzdžių (3 pav.) pirmą kartą matomai padaugèjo natų ornamento etapo (II) viduryje. Tačiau ne visi Žešuvo regiono gyventojai dalyvavo svetimšalių gaminių importe, dèl to didejo vidinè minètų bendruomenių diferenciacija. Buvo ir konservatyvių kultūrinių grupių, kurios laikèsi vietinių tradicijų, ir obsidiano ir Rytinès JLK kultūros importuotojų, palaikančių išorinius kontaktus (Kadrow 2020a, p. 100). Vèliau šie procesai igavo pagreitị ir tęsèsi natų ornamento (II) etapo pabaigoje, nors daugiausia suintensyvejo Želiezovce (III) etape.

Laikui bėgant, Žešuvo regiono JLK kultūros bendruomenèje plètėsi ritualinè veikla, kurią, be kita ko, irodo konkuruojančių keramikos ornamentikos stilių (natų ornamento, Želiezovce ir Rytinès JLK plitimas, kitaip tariant, dažnėjančios socialinių konfliktų situacijos. Taip pat augo gyventojų skaičius (7 pav.). Konfliktai tarp bendruomenių pasiekė aukščiausią intensyvumą JLK kultūros Želiezovce etapo (III) pradžioje, dèl to ịvyko kultūriniai pokyčiai ir JLK kultūra užleido vietą Melice kultūrai.

Šiuo straipsniu siekta atkreipti dèmesị i būtinybę susieti socializuoto individo (habitus) veiklą su ivairaus lygio globalizacijos procesais tarpiniuose etapuose (pvz., vietiniuose konfliktuose).

\section{ILIUSTRACIJŲ SĄRAŠAS}

1 pav. Dirbinių, pagamintų iš spondilų kriauklių, paplitimas $(\boldsymbol{C})$ lyginant su teritoriniu Juostinès linijinès keramikos kultūros $(\boldsymbol{A})$ ir Rytų juostinès linijinès keramikos kultūros $(\boldsymbol{B})$ pasiskirstymu (pagal Windler 2018), rodantis ankstyvojo neolito laikotarpio ryšius Europoje. A. Krzywdos pieš.

2 pav. Obsidiano paplitimas Europoje $(\boldsymbol{C})$ ir išgavimo vietos $(\boldsymbol{D})$ lyginant su teritoriniu Juostinès linijinès keramikos kultūros $(\boldsymbol{A})$ ir Rytų juostinès linijinės keramikos kultūros $(\boldsymbol{B})$ pasiskirstymu (pagal 
Burgert et al. 2017), rodantis ankstyvojo neolito laikotarpio ryšius Europoje. A. Krzywdos pieš.

3 pav. Importinės Rytų juostinès linijinès keramikos kultūros (c) pasiskirstymas šiauriau nuo Karpatų, rodantis kultūrines įtakas Juostinès linijinès (a) ir Želiezovce (b) keramikos stilių paplitimo teritorijose (pagal Kadrow, Rauba-Bukowska 2017). I. Jordan pieš.

4 pav. Žešuvas $(\boldsymbol{A})$, Krokuva $(\boldsymbol{B})$, Sandomieras $(\boldsymbol{C})$ ankstyvajame neolito laikotarpyje, mezolito (juodos linijos) ir Juostinès linijinès keramikos kultūros (raudonos linijos) ryšių tinklo kontekste (pagal Kozłowski, Nowak 2019). S. K. Kozłowskio ir M. Nowako pieš.

5 pav. Ribotas Želiezovce stiliaus (b) pasiskirstymas lyginant su Juostinès linijinès keramikos kultūros (a) išplitimu. A. Krzywdos pieš.
6 pav. Neolito laikotarpio gyvenvietės Žešuvo apylinkèse, pietryčių Lenkijai būdingame kraštovaizdyje. 1 - žemiausia upès slènio vieta; 2 - lioso atodanga upès salpoje; 3-5 - aukštesnès landšafto vietos su lioso nuosèdų sluoksniu; 6-10 - aukštesnès landšafto vietos be lioso nuosėdų. Ankstyvojo neolito gyvenvietès (pažymèta juodais taškeliais): 1 - Žešuvas 16; 2 - Žešuvas 20; 3 - Žešuvas 3; 4 Žešuvas 34; 5 - Zwięczyca 3 (pagal Kadrow 2020a). S. Kadrowo piěs.

7 pav. Demografiniai pokyčiai Žešuvo mikroregione Juostinès linijinès keramikos kultūros etapuose ir vystantis Melice keramikos kultūrai (plačiau Kadrow 1990a). S. Kadrowo pieš. 